\title{
Indigenous copper resistant bacteria isolated from activated sludge of water treatment plant in Surabaya, Indonesia
}

\author{
WAHYU IRAWATI ${ }^{1, \vartheta}$, REINHARD PINONTOAN ${ }^{2}$, TRIWIBOWO YUWONO ${ }^{3}$ \\ ${ }^{1}$ Department of Biology Education, Faculty of Education, Universitas Pelita Harapan. J1. M.H. Thamrin Boulevard 1100, Lippo Karawaci, Tangerang \\ 15811, Banten, Indonesia, Tel./fax.: +62-21-5460910, ^email: w.irawati3@gmail.com \\ ${ }^{2}$ Department of Biology, Faculty of Science and Technology, Universitas Pelita Harapan. Jl. M.H. Thamrin Boulevard 1100, Lippo Karawaci, Tangerang \\ 15811, Banten, Indonesia \\ ${ }^{3}$ Department of Agricultural Microbiology, Faculty of Agriculture, Universitas Gadjah Mada. Jl. Flora No. 1, Bulaksumur, Sleman 55281, Yogyakarta, \\ Indonesia
}

Manuscript received: 5 August 2020. Revision accepted: 8 October 2020.

\begin{abstract}
Irawati W, Pinontoan R, Yuwono T. 2020. Indigenous copper resistant bacteria isolated from activated sludge of water treatment plant in Surabaya, Indonesia. Biodiversitas 21: 5077-5084. Biological wastewater treatment using activated sludge is a promising wastewater treatment solution for removing heavy metals. To improve the effectiveness of biological wastewater treatment, activated sludge must consist of bacteria that can remove heavy metals through the process of bioaccumulation and biosorption. This study was aimed to isolate indigenous copper resistant bacteria and determining their resistance to copper, as well as analyzing their ability to accumulate and remove copper. Copper resistant bacteria were isolated from activated sludge of water treatment plant in industrial plant in Rungkut, Surabaya. Resistance to copper was analyzed by determining the value of minimum inhibitory concentration (MIC). The ability of bacterial isolates to remove copper was analyzed by atomic absorption spectrophotometer. A total of six highly copper resistant bacteria were isolated and designated as B6.1, C8.1, C9.3, C9.4, C9.5, C10.4 isolates. All isolates were categorized as high resistant bacteria with the MICs of $9-11 \mathrm{mM} \mathrm{CuSO}_{4}$. The two highest copper resistant bacteria were isolates C10.4 and C9.4. The ability of the two isolates to accumulate copper was $8.02 \mathrm{mg}$ and $4.83 \mathrm{mg}$ per gram dry weight of cells and to remove of copper up to $20.45 \%$ and $17.66 \%$, respectively.
\end{abstract}

Keywords: Copper accumulation, copper resistant-bacteria, water treatment

\section{INTRODUCTION}

The east coast of Surabaya, Indonesia known as Pamurbaya, is well known heavy metals-contaminated site especially with copper, zinc, nickel, lead, and chromium in Indonesia (Sari et al. 2017). Heavy metal pollution in Pamurbaya is caused by the disposal of untreated industrial waste surrounding the Rungkut area which produce more than 330 tons of waste per day (Arisandi 2013). Copper pollution in Pamurbaya is one of the serious cases of heavy metal pollution in Indonesia. Pollution at this location has resulted in high rate of fish deaths and brain damage of residents due to consumption of too much coppercontaminated fish. Copper is an essential element and enzyme cofactor such as oxidase and oxygenase. Overconsumption of copper resulted in intoxication and difficulty in excretion from the body (Rosahada et al. 2018). High levels of copper contamination, which reaches the amount of 939,000 tons, may damage the quality of the environment, as it interferes with chemical, physical, and the interaction of biotic and abiotic components (Zaidi et al. 2012).

According to Komesli (2014), biological wastewater treatment plant system by activated sludge is a promising solution for the removal of heavy metals from the environment. Chipasa (2003) reported that activated sludge in sludge particles was produced by growing some population of bacteria in aeration tanks. Activated sludge is added to wastewater, and the mixture is aerated and agitated for a certain time until it settled out by sedimentation and disposed of or reused for aeration tank. Activated sludge is a collection of biological flocks consisting of bacteria to remove pollutants from sewage treatment plants through precipitation (Pipeline 2003). Activated sludge consists of a mixed community of microorganisms, of which about 95 percent is dominated by aerobic bacteria and the remaining 5 percent are protozoa, rotifers, and invertebrates. The main principle of wastewater treatment using activated sludge is by allowing the growth of a bacterial community that collects together and formed floc which settles at the bottom as sludge. Mahmoudkhani et al. (2014) reported that the uptake of heavy metals by activated sludge involves physical, chemical, and biological processes including biosorption, accumulation, and extracellular adsorption by bacterial biopolymer, and solubility of heavy metals in activated sludge.

Biological wastewater treatment using activated sludge has been implemented by industrial communities in Rungkut before the disposal of the waste into the East coast of Surabaya. Wastewater treatment occurs repeatedly by utilizing a native indigenous bacterial community that grows naturally in activated sludge. The bacteria exposed in a long period during the wastewater treatment process 
enable them to adapt and thrive in the sludge and develop resistance to copper. Previous studies as reported by Kermani et al. (2010) demonstrated that some indigenous copper-resistant bacteria, Pseudomonas aeuroginosa, could be isolated from industrial activated sludge. Chellaiah (2018) found that heavy metals resistant bacteria Pseudomonas aeruginosa is ubiquitous in water ecosystems. Ralstonia pickettii strain DX-T3-01 and Sphingomonas sp. strain DX-T3-03 were two highly heavy metal resistant indigenous bacterial strains isolated from the biggest tailing in Asia-Dexing copper mine (Xie et al. 2010). Alcaligenes faecalis was the high heavy metals resistant bacteria isolated from sewage wastewater at Taif Province, Saudi Arabia (Abo-Amer et al. 2015). Rhizobium halophytocola strain KT327204.1 (RT7) isolated from soil around iron industries of Sonipat district in Haryana, India, also demonstrated resistance to metals (Gupta et al. 2015). Similarly, Proteus vulgaris, Serratia sp., and Pseudomonas sp. isolated from water samples of Ganga River in India were also copper resistant (Marzan et al. 2017).

The activated sludge contains bacterial communities that play an important role in wastewater treatment. The effectiveness of the biological system depends on the resistance and metabolic activities of the bacterial community in activated sludge during the wastewater treatment process. Copper-resistant bacteria may be employed for copper removal based on their capability in bioaccumulation and biosorption of copper. This study was aimed to isolate indigenous copper resistant bacteria and determining their resistance to copper, as well as analyzing their ability to accumulate and remove copper through accumulation and biosorption process. It is anticipated that the use of copper resistant bacteria will provide a novel and more effective system in wastewater treatment of coppercontaminated sites.

\section{MATERIALS AND METHODS}

Copper resistant bacteria were isolated from activated sludge of wastewater treatment plant in Surabaya industrial estate Rungkut, Indonesia. The growth medium used for bacterial isolate was Luria Bertani (LB). The solid medium was prepared with the addition of $2 \%$ pure agar and $2 \% \mathrm{LB}$ medium. Copper was made as a stock solution of $1 \mathrm{M}$ $\mathrm{CuSO}_{4}$ and added to the autoclaved media. One gram of activated sludge was dissolved in $100 \mathrm{ml}$ sterile water and inoculated by serial dilution on solid medium containing 2 $\mathrm{mM}$ of copper. The medium was incubated at $37^{\circ} \mathrm{C}$ for 24 hours. The growing bacterial colonies on the culture medium were selected and purified on the new medium containing $2 \mathrm{mM}$ of copper to obtain a single colony as a pure culture. The growth of bacterial communities was observed by growing cell cultures on medium containing various concentrations of copper.

Bacterial resistance to copper was determined by measuring the Minimum Inhibitory Concentration (MIC). The MICs were determined by streaking cell culture on solid medium with addition of $2 \mathrm{mM} \mathrm{CuSO}_{4}$ and incubated for 48 hours at $37^{\circ} \mathrm{C}$. The growing colonies were repeatedly streaked on the new medium containing higher concentration of copper until the bacterial colonies were unable to grow on the solid medium. Three highest copper resistant bacteria were subsequently used for analysis. Cells were grown in LB broth supplemented with various concentrations of copper and in medium without copper to observe the influence of copper on bacterial growth. The cultures were incubated at $37^{\circ} \mathrm{C}$ on a shaker at $175 \mathrm{rpm}$. The bacterial growth was monitored by measuring optical density at $600 \mathrm{~nm}$.

Biosorption was described by the quantity of copper removed from the growth medium compared to the initial concentration. Cells were grown in LB broth supplemented with copper and incubated at $37^{\circ} \mathrm{C}$ with shaking at 200 $\mathrm{rpm}$. Cells were centrifuged at $5000 \mathrm{xg}$ for $20 \mathrm{~min}$ at $4^{\circ} \mathrm{C}$ to separate supernatant from pellets. The supernatant was digested with $\mathrm{HNO}_{3}$ at $100^{\circ} \mathrm{C}$ to measure copper removal by bacterial isolates. Copper removal was determined by using an atomic absorption spectrophotometer at $324.9 \mathrm{~nm}$. To study the ability of bacterial isolates to accumulate copper, the cells were collected by centrifugation at 6000 $\mathrm{rpm}$ for $10 \mathrm{~min}$ at $4^{\circ} \mathrm{C}$ and washed several times with phosphate buffer. The cell pellets were digested with $\mathrm{HNO}_{3}$ at $100^{\circ} \mathrm{C}$. Copper content was determined by an Atomic Absorption Spectrophotometer (Irawati et al. 2019).

\section{RESULTS AND DISCUSSION}

\section{Isolation and characterization of copper resistant bacteria}

Activated sludge consists of bacterial communities having resistance towards copper and other pollutants in wastewater treatment system. The process of biological waste treatment plants is influenced by the composition of microorganisms in the activated sludge. The implementation of activated sludge occurs repeatedly in the wastewater treatment plants which resulted in the development of copper resistant bacteria. The sample solution of activated sludge was inoculated on to a solid medium containing $8 \mathrm{mM}, 9 \mathrm{mM}$, and $10 \mathrm{mM}$ of copper to observe the varieties of bacterial community growth (Figure 1). The results showed that various concentrations of copper in solid medium influenced the appearance of bacterial community. The number of bacterial communities grew on the medium decreased with the increase of copper concentration. The lowest number of bacterial communities was observed on medium containing the highest concentration copper, indicating that $10 \mathrm{mM}$ of copper was toxic for bacterial growth.

Table 1. Characteristics of copper resistant bacteria

\begin{tabular}{lllcc}
\hline Isolate code & Form & Color & Gram & $\begin{array}{c}\text { MICs of CuSO } \\
(\mathbf{m M})\end{array}$ \\
\hline B6.1 & Circular & White & - & 12 \\
C8.1 & Circular & Brown & - & 10 \\
C9.3 & Irregular & Cream & - & 10 \\
C9.4 & Circular & Brown & - & 12 \\
C9.5 & Circular & White & - & 9 \\
C10.4 & Irregular & White & - & 12 \\
\hline
\end{tabular}


Despite the fact that copper is a micronutrient necessary for bacterial growth and development (Nies 1999), high level of copper may impose deleterious effect on microbial communities. Copper toxicity may occur through the binding or blocking of functional group of biological molecules by copper which results in the inactivity of enzymes functions, as well as creates oxidative stress. The process of biological waste treatment plants is influenced by the composition of microorganisms in the activated sludge. The implementation of activated sludge occurs repeatedly in the wastewater treatment plants which resulted in the development of copper resistant bacteria. The sample solution of activated sludge was inoculated on to a solid medium containing $8 \mathrm{mM}, 9 \mathrm{mM}$, and $10 \mathrm{mM}$ of copper to observe the varieties of bacterial community growth (Figure 1). The results showed that various concentration of copper in solid medium influences the appearance of bacterial community. The number of bacterial communities grew on the medium decreased with the increase of copper concentration. The lowest number of bacterial communities was observed on medium containing the highest concentration copper, indicating that $10 \mathrm{mM}$ of copper was toxic for bacterial growth.

Figures 1 and 2 demonstrated that different communities, which also showed differences in the population number, thrived in the activated sludge as evidenced by the appearance of different colonies when cultured in $\mathrm{Cu}$-containing media. The observation thus suggests that different genetic and physiological background may contribute to the growth of different microbial communities, as also suggested by Rizvi et al. (2019) that differences in the number of microorganisms population may be attributed to differences in nutrients composition in the growth media, genetic background, and growth conditions.

Data also show that several different colonies appeared on the media supplemented with different $\mathrm{CuSO}_{4}$ concentrations of up to $10 \mathrm{mM}$, suggesting that these colonies were among indigenous populations which demonstrated higher tolerance to $\mathrm{Cu}$. Other indigenous microorganisms in the activated sludge may have been inhibited by the copper medium at elevated concentrations which, accordingly, did not survive when cultivated at high concentration of $\mathrm{Cu}$. This observation was in line with Ahemad (2012) suggestion that high concentration of heavy metals inhibits the metabolic activity of bacteria impacting the reduction of population numbers of a specific population, total microbial colonies, and the changes in the structure of the bacterial communities. The observation also supports the notion that the exposure of bacteria to high concentration of heavy metals for a long period resulted in development of resistance against heavy metals which subsequently out-growth other heavy-metalssensitive microorganisms (Chen et al. 2019). Copper resistant bacteria develop a resistance mechanism that enables them to thrive in a copper-contaminated environment for an extended period of time.

Altimera et al. (2012) reported differences in microbial communities that grew on copper contaminated-land along with that of uncontaminated land. Bacteria accustomed to live in heavy metal-contaminated habitats usually have a copA gene responsible for copper resistance mechanism. Irawati et al. (2016) reported that bacteria isolated from copper-contaminated sites developed resistance mechanisms by producing protein CopA to bind copper inside the cells. Figure 1 showed that the bacterial isolates could tolerate and grow on medium supplemented with 10 $\mathrm{mM}$ of copper. This observation indicated that copper contamination in the activated sludge is higher than 10 $\mathrm{mM}$. Manasi et al. (2016) reported that the resistance of bacterial isolates is an indication of the level of heavy metal pollution in the location where the bacteria were isolated. The structure of bacterial communities and total bacterial colonies changed with the increase of copper concentration from $8 \mathrm{mM}$ to $10 \mathrm{mM}$.

Table 1 presented the characteristics of copper resistant bacteria isolated from activated sludge wastewater treatment plant in Surabaya. A total of six copper resistant bacteria designated as B6.1, C8.1, C9.3, C9.4, C9.5, and $\mathrm{C} 10.4$ isolates were analyzed for their copper resistance. It is quite interesting to note that bacterial isolates obtained in this study demonstrated higher MIC than the previous studies (Irawati et al. 2019) as well as other studies carried out by Altimera et al. (2012). Irawati et al. (2012) reported that the highest copper resistant Klebsiella pneumoniae isolated from Cikapundung River in Indonesia has resistance to copper with the MIC of $8 \mathrm{mM} \mathrm{CuSO}_{4}$, while Altimera et al. (2012) showed that Sphingomonas sp., Arthrobacteria sp., and Stenotrophomonas sp., isolated from a copper mine in Valparaiso region, Chile demonstrated resistance to copper, $3.1 \mathrm{mM}$ to $4.7 \mathrm{mM}$ of copper. The bacteria which had MIC of $4.7 \mathrm{mM}$ were categorized as highly resistant. Therefore, microorganisms obtained in the present study can be categorized as highly resistant to $\mathrm{Cu}$.

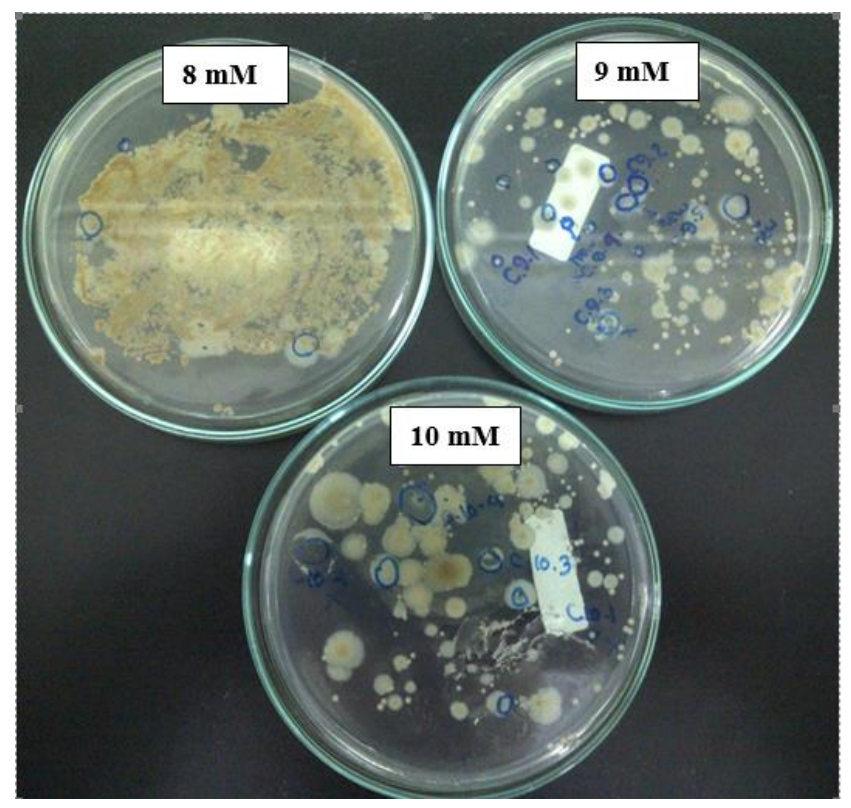

Figure 1. Communities of copper resistant bacteria grew on medium containing $8 \mathrm{mM}, 9 \mathrm{mM}$, and $10 \mathrm{mM} \mathrm{CuSO}_{4}$. 


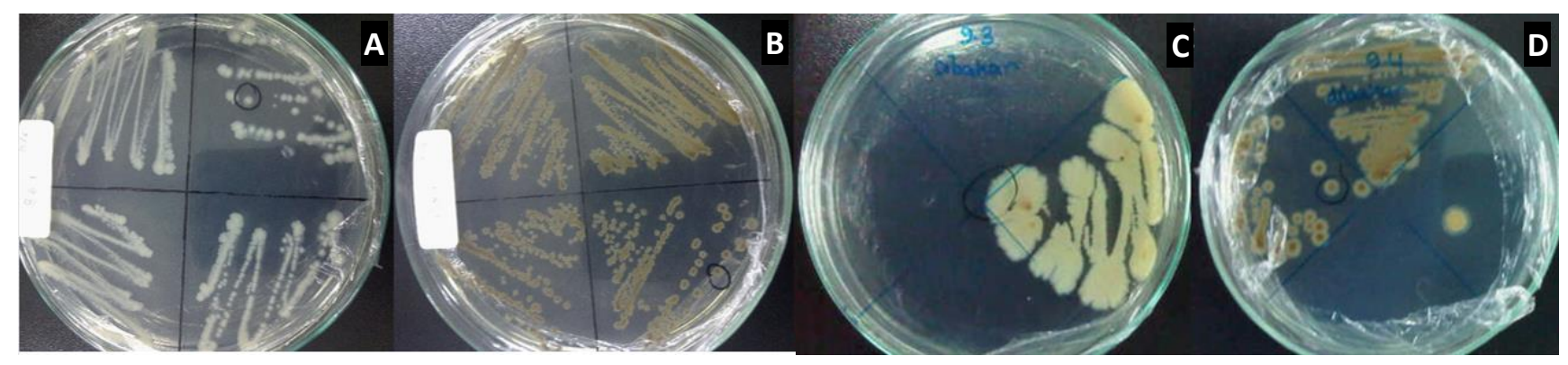

Figure 2. The growth of bacterial isolates on agar medium containing $9 \mathrm{mM} \mathrm{CuSO}_{4}$. (A) B6.1 (B) C8.1 (C) C9.3 (D) C9.4

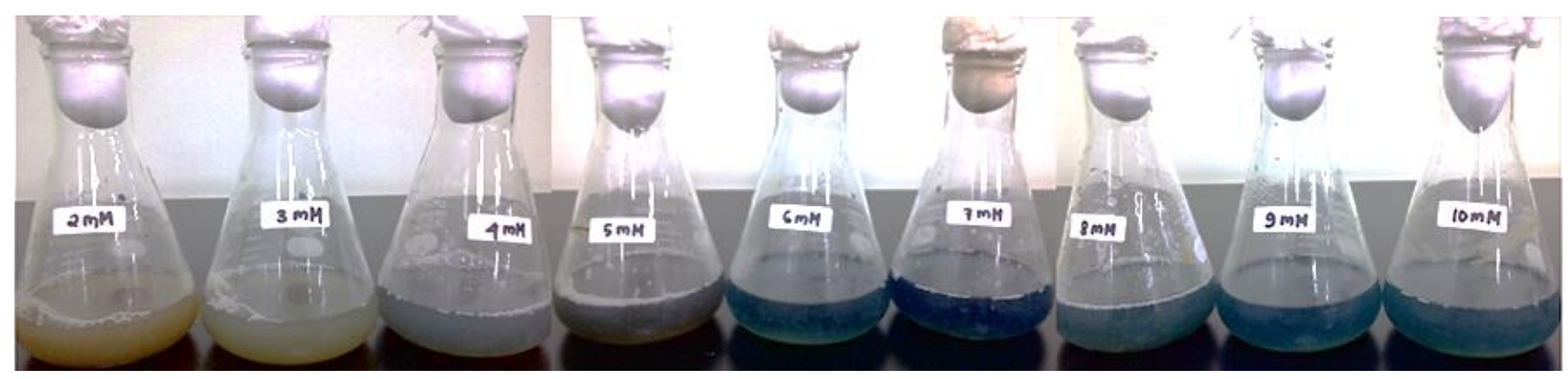

Figure 3. The growth of bacterial isolate $\mathrm{B} 6.1$ in $\mathrm{LB}$ broth medium containing 2-10 $\mathrm{mM} \mathrm{CuSO}_{4}$

Data on Table 1 also shows that all bacteria which showed high resistance to $\mathrm{Cu}$ obtained in this study were Gram-negative. This observation clearly suggests that Gram-negative bacteria tend to dominate the microbial communities in the activated sludge habitat, as also demonstrated in several previous studies. Irawati et al. (2019) demonstrated that all bacteria isolated from Cikapundung River were Gram-negative including Klebsiella pneumoniae CN6, Acinetobacter calcoaceticus CN2, Acinetobacter sp. CN5 and Escherichia coli CN8. Similarly, Adel et al. (2014) also reported that more than $60 \%$ of bacteria isolated from sewage were Gram-negative (Pseudomonas sp., Chryseomonas sp., and Kluyvera sp), while Benhalima et al. (2020) revealed that 12 strains copper resistant bacteria isolated from Seybouse River in Algeria were predominantly Gram-negative (Acinetobacter baumannii, Pseudomonas aeruginosa, Escherichia coli, Klebsiella oxytoca, Citrobacter freundii, Chryseobacterium indologenes, Raoultella ornithinolytica, Pasteurella trehalosi, Proteus vulgaris, Salmonella Typhimurium, Aeromonas hydrophila, and Shigella spp.). The facts that most of the copper resistant bacteria were predominantly of Gram-negative, raise the question of the underlying mechanism of copper resistant. It has been widely known that the outer membrane of Gram-negative bacteria contains strong negatively-charged components of carboxyl, amine, hydroxyl, phosphate and sulfhydryl groups that play a role in binding the positively-charged heavy metals (Tortora et al. (2005). According to Velkova et al. (2012), interactions between metals and bacteria depend upon the functional groups contained in the cell walls of Gram-positive or Gram-negative bacteria. The cell walls of Gram-negative bacteria consist of lipopolysaccharides, lipoproteins, and phospholipids as strong negatively-charged components that play a key role in major mechanism for copper binding. The results of this study suggested that Gram-negative bacteria are more resistant to copper compared to Gram-positive bacteria because of differences in membrane composition and the amount of negative charge between Gram-positive and Gram-negative bacteria.

\section{The influence of copper on bacterial growth}

The influence of copper on bacterial growth was observed not only based on MICs value but also from growth characteristics in broth medium. Isolate B6.1 was used as the model for studying the influence of various concentrations of copper-based on cell cultural color changes. The bacteria were grown in LB broth medium containing 2-10 $\mathrm{mM} \mathrm{CuSO}_{4}$. It was observed that microbial culture showed an increase in the turbidity which indicated cell growth. The level of copper inhibition was indicated by the changes in turbidity from light green to dark one. Light green indicated no inhibition by copper, while inhibition was marked by the appearance of dark green color. Based on these characteristics, it was demonstrated that the growth of isolate B6.1 was not inhibited by the addition of $2 \mathrm{mM}-5 \mathrm{mM}$ of copper. However, at higher copper concentrations, the color became darker due to growth inhibition of isolate B6.1 by copper at 6-10 mM concentrations present in the medium. 

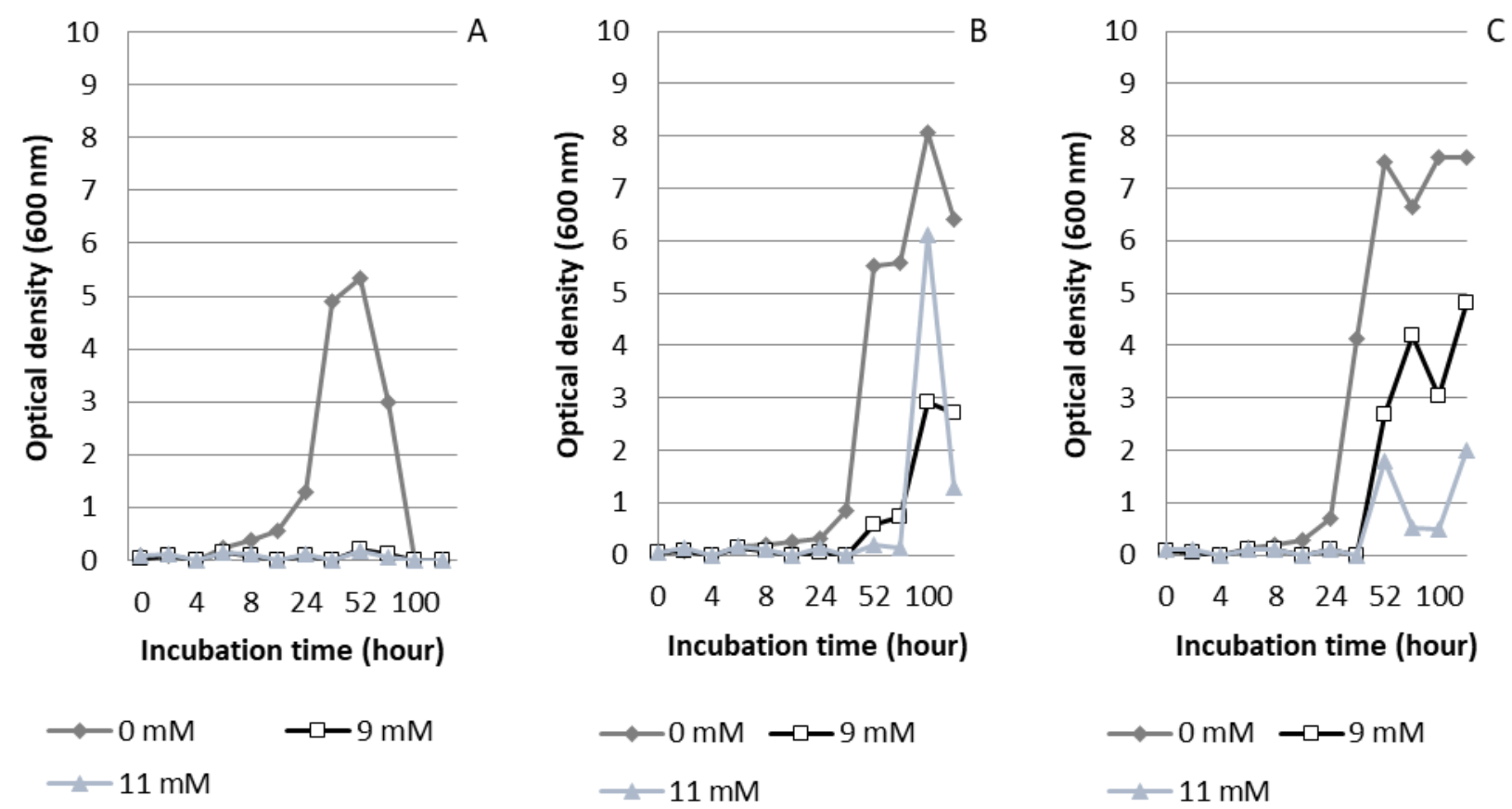

Figure 4. The growth of bacterial isolates in $\mathrm{LB}$ medium containing $9 \mathrm{mM} \mathrm{CuSO}_{4}, 11 \mathrm{mM} \mathrm{CuSO}_{4}$, and without copper. (A) Isolate B6.1 (B) Isolate C9.4 (C) Isolate 10.4.

$\mathrm{Li}$ et al. (2019) reported that copper at low concentration is a micro-element required for metabolic processes. At high concentrations, however, copper becomes toxic because it binds to functional groups and modifies it. Copper resistant bacteria have a resistance mechanism to neutralize copper toxicity. Changes in culture turbidity due to different copper concentrations, 2 mM-5 mM, suggested that the low copper concentration is required for bacterial growth. The copper concentration of $5 \mathrm{mM}$ is a threshold inhibitory concentration for the growth of bacterial isolate B6.1. The presence of copper starting from $6 \mathrm{mM}$ became a toxic condition which may be attributed to the binding of copper to a sulfhydryl group of enzymes resulting in the inhibition of metabolism activities.

Furthermore, the influence of a high concentration of copper was also observed based on growth pattern of isolates B6.1, C9.4, and C10.4. Figure 4 showed that the presence of copper at $9 \mathrm{mM}$ and $11 \mathrm{mM}$ concentration caused a decrease in growth activity and the extension of lag phase, even resulted in death. Isolate B6.1 demonstrated a lag phase for 4 hours, while isolates C9.4 and $\mathrm{C} 10.4$ required 8 hours before entering exponential phase when they were grown in medium without copper. It means that the three bacterial isolates required a long time to adapt and grow in the enrichment medium. Figure 4 showed that the presence of copper in the growth medium decreased growth activity. The longer lag phase, 28 hours, was observed when isolates $\mathrm{C} 9.10$ and $\mathrm{C} 10.4$ were subjected to copper at $9 \mathrm{mM}$, while isolate C10.4 required an even longer lag phase of 78 hours in medium supplemented with $11 \mathrm{mM}$ of copper.

It should be noted that the adaptation to grow at elevated copper concentration of the isolate B6.1, C9.4, and 10.4 requires 24-28 hours, followed by sharp increase of growth, despite the fact that peak of growth was different. Isolate C9.4 and 10.4 show higher growth than isolate B6.1 even at higher copper concentration. Aljerf and Almasri (2018) reported that heavy metals affected metabolic activity, membrane formation, and enzyme synthesis by extending the lag phase as a resistance mechanism. Irawati et al. (2012; 2016) showed that copper resistance mechanism in Acinetobacter sp. IrC1 involved copper accumulation inside the cells facilitated by protein. Chan et al. (2011) suggested that bacteria synthesized macromolecules and enzymes to degrade toxic compounds. Isolates C9.4 and C10.4, however, survived copper at higher concentrations by extending the lag phase as a mechanism of resistance to copper toxicity. The absence of growth activity of isolate B6.1 at high concentration of copper may be attributed to the inability to synthesize enzymes responsible for copper resistance mechanism.

The results of this study are in line with Haq et al. (2015) which reported that the growth of Kocuria rhizophila showed 9 hours of lag phase when grown in medium supplemented with heavy metal compared to growth in medium with no copper supplementation. The extension of lag phase may result in bacterial cells adaptation to high heavy metal concentrations. The inhibition of bacterial growth varies depending on the 
concentration of heavy metals in the medium. The decrease in growth activity is mainly due to the interaction of metal ions with negative groups on the cell surface such as phosphate, carboxyl, hydroxyl, and amino acids. According to Hobman and Crossman (2014), copper toxicity occurs due to the binding of copper ions with cellular components and bacterial biomolecules that block bacterial biological molecules which resulted in the damage of protein, DNA, and biological membrane, as well as disruption in enzyme and cellular functions.

\section{The ability of copper resistant bacterial isolates to accumulate and remove copper}

Exposure of bacteria to copper-contaminated habitat for an extended period of time forces the bacteria to develop copper resistance mechanisms. Mechanism employed in bacterial copper resistance includes bioaccumulation which involved complexation of metal ions inside and outside the cell by biosorption (Gupta et al. 2015). The ability of isolates C10.4 and C9.4 to accumulate copper is shown in Figure 6.

Isolates C10.4 and C9.4 accumulated copper at the level of $8.02 \mathrm{mg}$ and $4.83 \mathrm{mg}$ per gram dry weight of cells, respectively (Figure 6.A). The two isolates also demonstrated similar biosorption capacity, despite the fact that copper accumulation showed a more string difference (Figure 6A). This result is similar to the previous study of Irawati et al. (2019) which showed that bacterial strain CN1 isolated from Cikapundung River was capable of accumulating $4.62 \mathrm{mg}$ of copper. This result, however, was lower than the capability of Pseudomonas sp. strain SN7, SN28, and SN30 isolated from agricultural soils in India which accumulated $25 \mathrm{mg}-29 \mathrm{mg}$ of copper per gram dry weight of cells (Ahemad and Malik 2011).
Pseudomonas sp. strain SN7, SN28, and SN30 were resistant at $2.92 \mathrm{mM}$, while isolates $\mathrm{C} 10.4$ and $\mathrm{C} 9.4$ demonstrated higher resistance to copper at $9 \mathrm{mM}$ concentration, suggesting that high resistance does not necessarily linear to copper accumulation. It is, therefore, interesting to elaborate further on the underlying mechanism of copper accumulation and biosorption of the two isolated obtained in this study.

Bacteria have an affinity to bind copper by various mechanisms including accumulation in cell wall and complexion with carboxyl groups of the peptidoglycan in the cell wall (Ahemad and Malik 2011). It was suggested that the difference of copper accumulation ability between isolates C10.4, C9.4, and Pseudomonas sp. SN7, SN28, SN30 might be attributed to differences in the composition of cell wall carboxyl groups and composition of peptidoglycan which influence the capacity of copper accumulation in bacteria. The difference in the ability of copper accumulation between isolates $\mathrm{C} 10.4, \mathrm{C} 9.4$, and Pseudomonas sp. strain SN7, SN28, and SN30 may also be explained by the difference of copper resistance mechanism between the two groups. It was suggested that isolates C10.4 and C9.4 develop the efflux mechanism outside the cell to overcome the higher concentration of copper to hinder the toxicity of copper, as described by Sinha and Paul (2014). It was observed that mechanisms of adaptation to copper may be achieved by accumulation, biosorption, extracellular precipitation, and efflux of copper from the cell. Biosorption is a complex process consisting of ion exchange between amino and phosphate groups of nucleic acids, amides, and sulfhydryl groups found in bacterial biomass with copper ions (Murugavelh and Vinothkumar 2010).

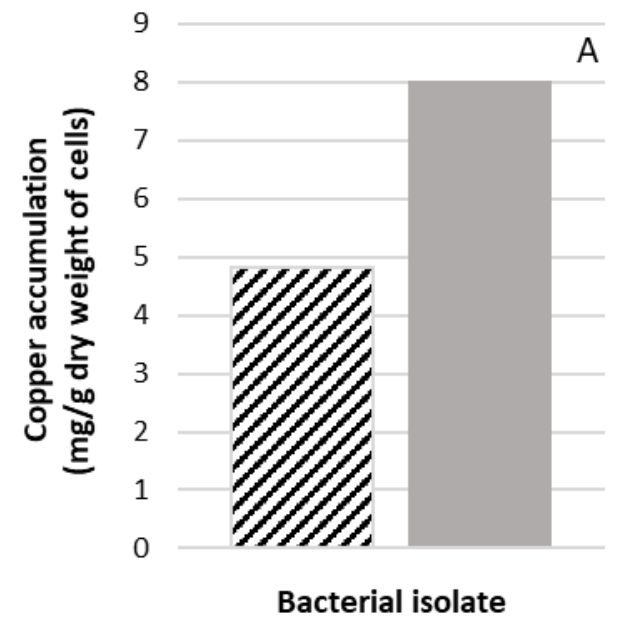

$>C 9.4 \square C 10.4$

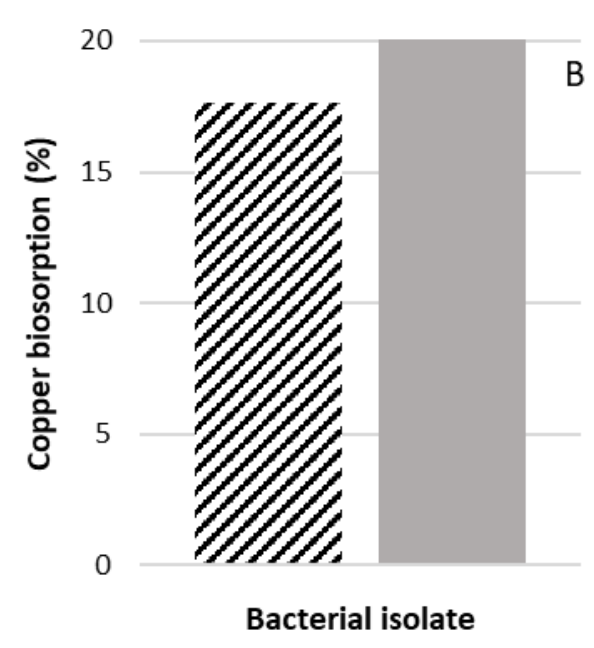

ᄀ.C $9.4=\mathrm{C} 10.4$

Figure 6. The potency of copper resistant bacterial isolates to accumulate and biosorp of copper. A. Copper accumulation, B. Copper biosorption 
Copper biosorption mechanism is a combination of several binding reaction processes between copper and functional groups on the cell wall surface. The biosorption mechanism includes two stages, passive and active (Hansda et al. 2015). The first step is passive biosorption, which is an extracellular binding of the cell wall surface, independent of the metabolism process. The second stage is a process that involves metabolism. This process occurs slowly due to the penetration of copper ions into the cell membrane, or intracellular binding (Hansda et al. 2015). Figure 6(B) showed the percentage of copper biosorption by copper resistant bacterial isolates $\mathrm{C} 10.4$ and $\mathrm{C} 9.4$ were $20.45 \%$ and $17.66 \%$, respectively. The ability to remove copper by those isolates was lower than tolerant bacterial isolate as reported by Al-Gheethi et al. (2014) that tolerant bacterial isolate was efficient in removing copper of up to $74.61 \%$. While, Irawati et al. (2019) reported that strain CN8 demonstrated copper removal with a value of $48.15 \%$. Biomass cell walls contain polysaccharide and lipid proteins that provide functional groups for binding of copper ions. The lower ability of isolates C10.4 and C9.4 in copper removal than other isolates might be due to their lower capacity of binding sites.

This study demonstrated that six highly copper resistant bacteria have been isolated from activated sludge wastewater treatment plants with the MICs of 9-11 mM $\mathrm{CuSO}_{4}$. Isolates $\mathrm{C} 10.4$ and $\mathrm{C} 9.4$ showed highly copper resistance. Isolates C10.4 and C9.4 accumulated copper at the level of $8.02 \mathrm{mg}$ and $4.83 \mathrm{mg}$ per gram dry weight of cells, respectively, while the copper biosorption of isolates C10.4 and C9.4 were $20.45 \%$ and $17.66 \%$, respectively. It is anticipated that high resistance to copper of these isolates may be developed as bioaccumulator and biosorbent in wastewater treatment system to solve environmental problem imposed by copper contamination. Data obtained in this study thus underline the facts that microbial growth in heavy metal-contaminated sites was correlated with the physiological and genetic background of the microorganisms which is reflected in differences in microbial communities thrived and outgrowth of other heavy-metal sensitive microorganisms. The fact that Gramnegative bacteria dominate the communities of the coppercontaminated site, suggests that Gram-negative bacteria may have evolved its tolerance to copper throughout their evolutionary process. However, it is quite interesting to explore further the differences in detailed mechanisms of copper tolerance between Gram-negative and Grampositive bacteria.

\section{ACKNOWLEDGEMENTS}

The authors thank the Laboratory of Biology, Faculty of Science and Technology, Universitas Pelita Harapan, Indonesia for funding support. We would like to thank students of the Biology Department, Universitas Pelita Harapan for their assistance in accomplishing this project.

\section{REFERENCES}

Abo-Amer AE, El-Shanshoury AE-R, Alzahrani OM. 2015. Isolation and molecular characterization of heavy metal-resistant Alcaligenes faecalis from sewage wastewater and synthesis of silver nanoparticles. Geomicrobiol J 32: 836-845.

Adel AS, Gheethi A, Norli I, Lalung J, Azlan AM, Farehah ZN, Kadir MOA. 2014. Biosorption of heavy metals and cephalexin from secondary effluents by tolerant bacteria. Clean Technol Environ Pol 16 (1): 137148 .

Ahemad M. 2012. Implication of bacterial resistance against heavy metals in bioremediation: a review. J Inst Integrat Omics Appl Biotechnol 3 (3): 39-46.

Ahemad M, Malik A. 2011. Bioaccumulation of heavy metals by zinc resistant bacteria isolated from agricultural soils irrigated with wastewater. Bacteriol J 2 (1): 12-21.

Al-Gheethi AA, Norli L, Lalung J, Azlan AM, Farehah ZN, Kadir MOA. 2014. Biosorption of heavy metals and from secondary effluents by tolerant bacteria. Curr World Environ 16 (1): 137-148.

Aljerf L, Almasri N. 2018. A gateway to metal resistance: bacterial response to heavy metal toxicity in the biological environment. Ann Adv Chem 2: 32-4.

Altimira F, Yáñez C, Bravo G, González M, Rojas LA,Seeger, M. 2012. Characterization of copperresistant bacteria and bacterial communities from copper-polluted agricultural soils of central Chile. BMC Microbiol 12: 1-12.

Arisandi P. 2013. The Rufford Small Grants for Nature Conservation. Rufford Foundation, UK. http://www.rufford.org/rsg/projects/prigi_arisandi

Benhalima L, Amri S, Bensouilah M, Ouzrout R. 2020. Heavy metal resistance and metallothionein induction in bacteria isolated from Seybouse river, Algeria. Appl Ecol Environ Res 18 (1): 1721-1737.

Chan KG, Atkinson S, Mathee K, Sam CK, Chhabra SR, Camara M, Koh CL, Williams P. 2011. Characterization of N-acyl homoserine lactone degrading bacteria associated with Zingiber officinale (ginger) rhizosphere: Co-existence of quorum quenching and quorum sensing in Acinetobacter and Burkholderia. BMC Microbiol 11 (1): 51.

Chellaiah ER. 2018. Cadmium (heavy metals) bioremediation by Pseudomonas aeruginosa: a minireview. Appl Water Sci 8: 154.

Chen J, Li J, Zhang H, Shi W, Liu Y. 2019. Bacterial heavy-metal and antibiotic resistance genes in a copper tailing dam area in Northern China. Front Microbiol 1-12. DOI: DOI: 10.3389/fmicb.2019.01916.

Chipasa KB. 2003. Accumulation and fate of selected heavy metals in a biological wastewater treatment system. Waste Manag 23 (2003): 135-143.

Gupta R, Kumar T, Mittal A. 2015. Isolation, identification and characterization of heavy metal resistant bacteria from soil of an iron industry, Haryana (India). Intl J Pharm Sci Res 7 (3): 1308-1313.

Hansda A, Kumar V, Anshumali. 2015. Biosorption of copper by bacterial adsorbents: a review. Res J Environ Toxicol 9 (2): 45-58.

Haq F, Butt M, Ali H, Chaudhary HJ. 2015. Biosorption of cadmium and chromium from water by endophytic Kocuria rhizophila: equilibrium and kinetic studies. Desalin Water Treat 57 (42): 19946-19958.

Hobman JL, Crossman LC. 2014. Bacterial antimicrobial metal ion resistance. J Med Microbiol 64: 471-497.

Irawati W, Ompusunggu NP, Susilowati DN, Yuwono T. 2019. Molecular and physiological characterization of indigenous copper-resistant bacteria from Cikapundung River, West Java, Indonesia. Biodiversitas 20 (2): 344-349.

Irawati W, Yuwono T, Rusli A. 2016. Detection of plasmids and curing analysis in Copper Resistant Bacteria Acinetobacter sp. C1, Acinetobacter sp. C2, and Cupriavidus sp. C4. Biodiversitas 17 (1): 296-300.

Irawati W, Yuwono T, Soedarsono J, Hartiko H. 2012. Molecular and physiological characterization of copper-resistant bacteria isolated from activated sludge in an industrial wastewater treatment plant in Rungkut-Surabaya, Indonesia. Microbiol Indones 6 (3): 3-3. [Indonesian]

Kermani AJN, Ghasemi MF, Khosravan A, Farahmand A, Shakibaie MR. 2010. Cadmium bioremediation by metal-resistant mutated bacteria isolated from active sludge of industrial effluent. Iran J Environ Health Sci Eng 7 (4): 279-286. 
Komesli OT. 2014. Removal of heavy metals in wastewater by membrane bioreactor effects of flux and suction period. J Chem Soc Pak 36 (4) 654-659.

Li C, Li Y, Ding C. 2019. The role of copper homeostasis at the hostpathogen axis: From bacteria to fungi. Int J Mol Sci 20 (1): 175

Mahmoudkhani R, Torabian A, Hassani AH, Mahmoudkhani R. 2014. Copper, cadmium and ferrous removal by membrane bioreactor. APCBEE 10: 79-83.

Manasi, Rajesh N, Rajesh V. 2016. Evaluation of the genetic basis of heavy metal resistance in an isolate from electronic industry effluent. J Genet Eng Biotechnol 14: 177-180.

Marzan LW, Hossain M, Mina SA, Akter Y, Chowdhury AM. 2017 Isolation and biochemical characterization of heavy-metal resistan bacteria from tannery effluent in Chittagong city, Bangladesh: Bioremediation viewpoint. Egypt J Aquat Res 43 (1): 65-74.

Murugavelh S, Vinothkumar D. 2010. Removal of heavy metals from wastewater using different biosorbents. Curr World Environ 5 (2) 299-304

Nies DH. 1999. Microbial heavy-metal resistance. Appl Microbiol Biotechnol 51: 730-750.

Pipeline. 2003. Explaining the activated sludge process. Spring 14 (2): 1 8.
Rizvi A, Ahmed B, Zaidi A et al. 2019: Heavy metal-mediated phytotoxic impact on winter wheat: oxidative stress and microbial management of toxicity by Bacillus subtilis BM2. RSC Adv 9: 6125-6142.

Rosahada AD, Budiyono, Dewanti NA. 2018. Biokonsentrasi logam berat tembaga $(\mathrm{Cu})$ dan pola konsumsi ikan mujair di wilayah danau Rawapening. Jurnal Kesehatan Masyarakat 6 (6): 1-7. [Indonesian]

Sari, SH, Kirana JF, Guntur. 2017. Analisis kandungan logam berat Hg dan $\mathrm{Cu}$ terlarut di Perairan Pesisir Wonorejo, Pantai Timur Surabaya. Jurnal Pendidikan Geografi 22 (1): 1-9. [Indonesian]

Sinha SN, Paul D. 2014. Heavy metal tolerance and accumulation by bacterial strains isolated from wastewater. J Chem Biol Phy Sci 4 (1): 812-817.

Tortora GJ, Funke DR, Case CL. 2005. Microbiology: An Introduction. 8th ed. Benjamin Cummings, San Fransisco, CA.

Velkova Z, Stoytcheva M, Gochev V. 2012. Biosorption of Cu (II) onto chemically modified waste mycelium of Aspergillus awamori: equilibrium, kinetics and modeling studies. J Biosci Biotechnol 1 (2): 163-169.

Xie X, Fu J, Wang H, Liu J. 2010. Heavy metal resistance by two bacteria strains isolated from a copper mine tailing in China. Afr J Biotechnol 9 (26): 4056-4066

Zaidi A, Wani PA, Khan MS. 2012. Toxicity of Heavy Metals to Legumes and Bioremediation. Springer, Pondicherry. 